\title{
History of Changes in the Evaluation System on Membership Sports Organizations of the Korean Sport \& Olympic Committee
}

\author{
Misuk Kim ${ }^{1}$, Jayoung $\mathrm{Kim}^{2}$ and Jooyoung $\mathrm{Kim}^{2 *}$ \\ ${ }^{1}$ Korea Institute of Sport Science, Seoul, Korea \\ ${ }^{2}$ Korea National Sport University, Seoul, Korea
}

\author{
Article Info \\ Received 2021.10.22. \\ Revised 2021.11.22. \\ Accepted 2021.11.25. \\ Correspondence* \\ Jooyoung Kim \\ kjm3409@naver.com

\section{Key Words} \\ Membership sports \\ organizations of Korean Sport \& \\ Olympic Committee, \\ Evaluation system, \\ Policy evaluation, \\ Organization management
}

PURPOSE This study compared and analyzed the current status, system, and trend of evaluation and operation of member sports organizations of the Korean Sport \& Olympic Committee from 2006 to 2020. METHODS A literature study was conducted for this study. RESULTS The 15-year evaluation was developed through three periods: preparation, execution, and construction. The preparation stage (2006-2009) was when the evaluation index development and operation system were established. The execution stage (2010-2016) is a critical time; when the current system was established. This was when evaluation perception was spread in the sports world and continuous changes such as evaluation system and operation, indicators. Finally, the construction stage (2017-2020) was when the evaluation system was established after integrating the Korean Sport \& Olympic Committee and the National Sports Council. CONCLUSIONS It played a role in promoting balanced growth from organizational management to ethical management of sports organizations through preparation, execution, and construction. Further, the evaluation reflected the continuous development and change of the Korean sports community and one organizational assessment.

\section{서론}

조직의 전략 목표, 성과목표 및 성과를 측정할 지표가 결정된 후에는 구 체적으로 성과측정 및 성과평가가 이루어진다. 성과측정(performance measurement)이란 목표를 달성하기 위해 행해지는 활동과 그 결과를 계속적으로 점검하는 것이다(Park, 2005).

2006년 정부업무평가기본법에 성과관리가 도입되면서 우리나라 평가제도는 심사분석-정책평가(기관평가)-성과관리로 이어지는 패러 다임의 변화를 겪고 있다(Yoon et al., 2008). 성과평가는 책임성을 강화하고 동기를 부여하는 중요한 목적을 갖고 있다. 영국은 정책평 가의 선진국이면서 1980 년대 이후 공공 부문 개혁에 성공한 대표적 인 국가이고(Kim, 2004; Lee, 2009; Seo, 2005), 캐나다는 각 부처 의 성과계획서, 성과보고서, 각종 성과관리 지침, 성과 $\mathrm{DB}$ 등을 관리 하고 공개하고 있다(Yoon et al., 2008).

이러한 국내외 평가 제도를 체육계에서도 2006년 8월 「경기단체

(cc) This is an open-access article distributed under the terms of the Creative Commons Attribution Non-Commercial License (http://creativecommons.org/ licenses/by-nc/4.0/), which permits unrestricted non-commercial use, distribution, and reproduction in any medium, provided the original work is properly cited.
성과지표 개발 및 평가,라는 명칭으로 시작하였으며, 경기단체 사업 과 조직성과를 평가하였다. 2008년에는 2007년을 대상으로 경기단 체의 “경기력지원비 지원사업”만을 평가한 기록을 찾을 수 있었다 (KISS, 2008). 15여년 뒤인 2021년에는 “체육단체 혁신 평가"라는 명 칭으로 평가가 수행되고 있다.

그동안 대한체육회 회원종목단체의 평가 목적은 첫째, 합리적이고 객관적인 성과평가와 관리를 통해 회원종목단체 운영 발전방향 제시, 둘째, 회원종목단체의 경쟁력 확보 및 효율적인 단체관리를 지원, 셋 째, 평가를 통해 투명하고 합리적인 조직운영 체계 및 선순환 구조 마 련으로 국민체육진흥을 이바지한다. 이러한 목적에 따라 2006년 「경 기단체 성과지표 개발 및 평가」이후 2021년까지 평가가 실시되었고, 종목단체들의 효율적이고, 투명한 조직 운영 및 체계 구축에 기여하 였다는 데에 긍정적인 효과를 거두고 있다. 게다가 평가결과에 따라 회원종목단체에게 인센티브 및 경기력향상지원비를 차등 배분하기에 평가결과가 회원종목단체 운영에 긍정적 영향을 미칠 것에 대한 기대 가 상당히 크다.

한편 정부 기조 및 시대를 반영하여 기존 선진화 평가 개선에 대한 사회적 요구가 높아지고 있다. 2016년 통합체육회 출범, 2019년 스 포츠혁신위원회의 권고안, 2020년 국민체육진흥법 개정, 2021년 시 
도체육회 법정법인화 등 환경적 변화는 체육단체들의 혁신과 자정능 력 강화를 적극적으로 요구하고 있다. 이러한 배경으로 평가명칭, 평 가주체, 평가체계 및 지표 등의 변화는 대한민국 체육단체 운영 및 평 가 전반에 영향을 미쳤다.

그러나 지금까지 대한체육회 회원종목단체 평가에 대한 분석이나 고찰 연구는 전무하다. 다만 체육단체 평가, 평가지표 등 핵심어를 찾 았을 때 학술논문으로 체육단체 윤리경영 제고를 위한 지표조사 및 기반구축(Lee et al., 2011), 국내 체육단체의 윤리경영 제고를 위한 측정지표 개발(Shin, 2014), 공공체육단체의 윤리경영 모델 개발 및 촉진 방안(Kim \& Hong, 2009), 공공체육단체 경영평가제도의 유효 성 요인 척도 개발(Lee et al., 2006) 등이 있는데 대부분 대한체육회, 국민체육진흥진흥공단 등 대표적인 체육기관을 대상으로 하였다. 이 는 자료 접근의 어려움 때문이었을 것이라 예상된다. 따라서, 본 연구 는 종목단체 평가와 관련된 전반적인 내용에 대한 역사적 고찰에 초 점을 두고 첫 시도를 하고자 한다. 선행연구는 한국스포츠정책과학원 과 대한체육회 보고서, 학술논문 및 회원종목단체 평가편람자료를 기 초 자료로 활용하였다. 2019년 기준, 연간 약 940억원부터 3천만원 의 예산으로 운영되는 대한체육회 회원종목단체들에 대한 평가의 중 요성은 굳이 강조할 필요가 없을 듯 하다. 회원종목단체는 해당 종목 운동을 국민에게 보급하고, 운동선수를 양성하여 국위선양에 이바지 하며, 국제체육기구에 대한 독점적 교섭권을 갖는 해당 종목의 유일 한 단체이자 대한민국을 대표하기 때문이다.

그러므로 본 연구는 2006년부터 시작된 대한체육회 회원종목단체 평가에 대한 다각적 분석을 위해 시대적 배경, 평가 운영 체계 변천 등 의 과정을 살펴보았으며 이를 통해 앞으로 체육단체 평가제도의 방향 성에 대한 제언을 기술하였다. 이를 통해 단순히 각 조직에 대한 평가 결과를 도출하는 것이 아닌 한국스포츠의 지속적 발전을 위해 각 회 원종목단체들이 주춧돌 역할을 할 수 있도록 뒷받침되고자 한다.

\section{통합 대한체육회 전후로 본 평가 체계에 대한 소고}

정부는 기금을 받는 모든 기관을 대상으로 기관 및 개별사업에 대해 평가하여 재원배분의 판단기준으로 삼고 있으며, 1999 년 기획예산위 원회에서는 성과주의 예산제도를 도입하였다(Park, 2006). 이러한 환 경 변화로 대한체육회와 국민체육진흥공단도 평가 대상에 포함된다. 따라서 평가 구조에서 대한체육회를 거쳐 기금을 지원받는 종목단체 에 대한 평가는 필수적이다. 이는 종목단체의 행정 및 운영 방식을 개 선하여 지원 사업의 효과를 높이고, 정부 정책 기조가 모든 체육단체 까지 확대 적용시킬 수 있도록 하는 의의를 갖고 있다. 그리고 평가가 시작되는 시기에 국민체육진흥기금 운용평가 과정에서 경기력향상지 원비에 대해 경기단체 평가 및 감독이 이루어지지 않는다는 지적이 있 었고, 특히 경기력향상지원비 규모 증대에 따라 경기단체의 사업 체계 변화를 요구하고 있었다(KISS, 2006). 아울러 정부(기획예산처)의 재 정운영 방향 및 방침은 지원한 재정을 통합적으로 관리 및 평가하고, 경기단체가 경쟁을 통해 발전하도록 하는 방향을 설정하고 있다.

본 장에서는 2021년 체육단체 혁신평가까지 약 15년 동안 이어진 대한체육회 회원종목단체 평가 지표 및 운영 과정의 변화를 고찰하고 자 한다. 우선 평가에 대한 이해를 위해 준비기, 실행기, 구축기로 구 분하였고, 각 시기별 평가에 대한 세부적인 내용은 아래와 같다.

\section{준비기(2006-2008)}

준비기는 단체 평가를 위한 초기 단계로 평가에 대한 배경, 필요 성, 이론, 실제 그리고 평가지표 개발 및 운영 구상에 초점을 두었다. 2006년 8월 「경기단체 성과지표 개발 및 평가」는 현재 체육단체 혁신 평가의 시초이며 경기단체를 평가하는 데에 있어 지표 개발 및 평가 운영에 대한 전반적인 내용을 다루고 있다. 이를 토대로 2008년 12월 에 발표된「경기단체의 성과평가」에서는 2007년 경기단체 경기력향 상지원비 지원사업만을 대상으로 평가한 결과보고서이다.

몇몇 기록에 의하면 경기단체 평가는 2010년부터 시작하였다고 하 나 2006년에 경기단체 평가 지표 개발, 2008년에는 지원된 경기력향 상지원비만을 대상으로 경기단체 평가를 실시한 것으로 나타났다. 아 래는 2006년부터 2008년까지 준비기 동안 경기단체 평가 도입배경 및 운영 등 전반에 대한 내용을 기술하였다.

\section{1. 근거}

대한체육회 정관 7조 5항에 의하면, 가맹경기단체는 해당 단체의 목적 사업을 수행하는 데서 필요한 경우 국고보조금 또는 국민체육진 흥공단 지원금을 대한체육회를 통해서 요청하도록 되어 있다. 8조에 의하면 가맹경기단체는 대한체육회의 정관, 규정 및 결의된 지시사 항을 준수할 의무가 규정되므로 당시 평가운영에 대한 직접적 근거는 없고 대한체육회 정관을 제시한 것으로 보여진다.

\section{2. 목적}

2006년 「경기단체 성과지표 개발 및 평가」는 대한민국 체육계 역 사상 처음으로 만들어진 경기단체 평가 계획(안)이라 볼 수 있다. 그 목적은 정부 정책기조에 부응하여 대한체육회 경기단체의 운영성과 를 평가할 합목적적이고 합리적인 지표를 개발하고, 이를 적용하여 관리할 평가체계의 시범안을 도출하는 데에 있다(KISS, 2006). 2008 년 「경기단체의 성과평가」에서 평가의 목적은 2007년 지원한 경기단 체 경기력지원비를 대상으로 한 사업평가이다(KISS, 2008). 아울러 이전 2006년 개발된 성과지표를 현장에 적용토록 개선하고, 가맹단 체에 평가 시행에 대한 동의 및 절차를 강화하는 것 또한 목적에 반영 되어 있다.

\section{3. 평가 체계}

2006년은 평가 초기인 만큼 체계를 마련하는 데에 고심한 흔적을 살펴볼 수 있다. 우선 평가 주체는 대한체육회로 지정하였는데 그 이 유는 경기력 향상을 위해 기금보조금을 수령·교부하고, 이외 기금의

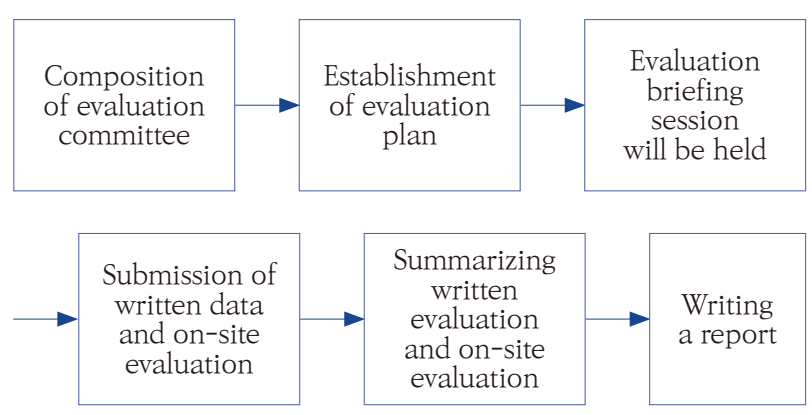

Fig. 1. The 2006 evaluation system(KISS, 2006) 


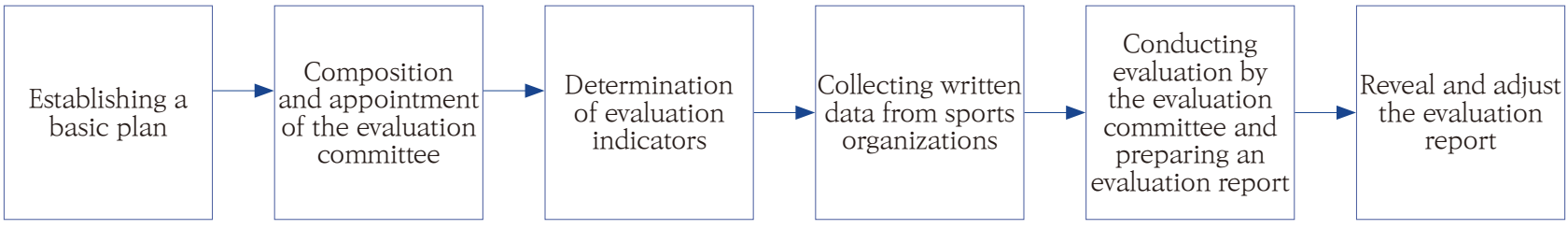

Fig. 2. The 2008 evaluation system(KISS, 2008)

Table 1. 2006 Performance indicators

\begin{tabular}{|c|c|c|c|}
\hline Work area & $\begin{array}{l}\text { Business according to the } \\
\text { articles of incorporation }\end{array}$ & Details business group & Details performance indicators \\
\hline \multirow{9}{*}{ Sports supply } & \multirow{5}{*}{$\begin{array}{l}\text { Promoting and } \\
\text { enlightening the game }\end{array}$} & \multirow{3}{*}{ Supplies } & The distribution results of classroom projects \\
\hline & & & Development and distribution of map programs \\
\hline & & & Number of people participating in activities \\
\hline & & \multirow{2}{*}{ promotion } & Sports news coverage \\
\hline & & & Daily reports in Korea \\
\hline & \multirow{3}{*}{$\begin{array}{l}\text { Management and supervision } \\
\text { of affiliated federations and } \\
\text { municipal branches }\end{array}$} & \multirow{3}{*}{ Build relevant infrastructure } & The formation rate of municipalities and districts \\
\hline & & & Exchange results with city, county, and district branches \\
\hline & & & The formation rate of club members \\
\hline & $\begin{array}{l}\text { Other projects necessary } \\
\text { for achieving the purpose } \\
\text { of the plenary session }\end{array}$ & $\begin{array}{l}\text { The business characteristic of the } \\
\text { relevant sports organization }\end{array}$ & Characteristic business indicators \\
\hline \multirow{9}{*}{$\begin{array}{c}\text { Running a } \\
\text { domestic } \\
\text { championship }\end{array}$} & \multirow{3}{*}{ Related to games } & Giving the player rights & Giving the player rights \\
\hline & & \multirow{2}{*}{ Games } & Appropriateness of the number of national competitions \\
\hline & & & Class loss rate of student athletes \\
\hline & \multirow{3}{*}{$\begin{array}{l}\text { Training of athletes, } \\
\text { referees, } \\
\text { operational personnel, etc }\end{array}$} & \multirow{3}{*}{ Fostering related personnel } & The number of players \\
\hline & & & Number of domestic judges, number of international judges \\
\hline & & & Number of game leaders \\
\hline & \multirow{2}{*}{$\begin{array}{l}\text { Research, installation, and } \\
\text { management of game facilities }\end{array}$} & \multirow{2}{*}{ Establishing related infrastructure } & Budget rate for research and education \\
\hline & & & Securing rate of exclusive facilities \\
\hline & $\begin{array}{l}\text { Other projects necessary } \\
\text { for achieving the purpose } \\
\text { of the plenary session }\end{array}$ & $\begin{array}{l}\text { The business characteristic of the } \\
\text { relevant sports organization }\end{array}$ & Characteristic business indicator \\
\hline \multirow{5}{*}{$\begin{array}{l}\text { International } \\
\text { exchange }\end{array}$} & \multirow{5}{*}{$\begin{array}{l}\text { Hosting and participating } \\
\text { in international competitions }\end{array}$} & \multirow{3}{*}{ Hosting an international competition } & Whether it's a championship or not \\
\hline & & & Whether or not it is broadcasted in the relevant country \\
\hline & & & Domestic ratings \\
\hline & & $\begin{array}{l}\text { Participating in international } \\
\text { competitions }\end{array}$ & Performance by competition level \\
\hline & & International exchange & The ratio of executives of international organizations \\
\hline
\end{tabular}

(KISS, 2006) 
위탁교부를 행하는 기관이면서 동시에 단체들의 사업을 관리·감독하 는 책무를 갖고 있기 때문이다. 대한체육회 내 실제 평가 업무를 수행 하기 위한 담당부서는 혁신평가실과 경기운영부가 제안되었다. 그리 고 외부전문가로 구성된 가칭)경기단체 평가위원단을 설치하여 평가 에 대한 자문, 사업 평가, 최종 평가보고서 작성, 지표 개선 등의 역할 을 부여하였다. 담당부서 및 평가위원단 구성은 평가 업무의 총괄과 전문성·객관성을 강화시키는 중요한 계기라 할 수 있다.

평가 체계 중 평가군 구분은 핵심 사항이라 할 수 있는데 50 여개의 다양한 종목 특성과 규모를 가진 단체를 군별로 나눈 것이다. 이 때 세 개의 그룹(C1 C3)으로 구분한 바 $\mathrm{C} 1$ (14개 종목)은 경기력 중심 종목 ${ }^{1)}$ $\mathrm{C} 2$ (16개 종목)는 종목 보급 중심 종목 ${ }^{2}, \mathrm{C} 3$ (23개 종목)은 절충형 종 목3)으로 구분하였다.

2008년에는 종목단체를 2개군으로 구분하였는데 가군(올림픽 종 목 $)^{4}$ 과 나군(가군을 제외한 종목으로 아시안게임종목과 이외 종목 $)^{5)}$ 이다. 당시 자료에 의하면 나군의 경우 올림픽 및 아시안게임 종목을 제외한 종목들로 자료를 확보하지 못하거나, 평가의 이해가 충분하지 못한 이유들로 제대로된 평가를 하지 못했다는 어려움을 엿볼 수 있 다(KISS, 2006).

4. 평가 지표

평가를 위한 첫 해였던 만큼 지표 개발에 또한 중점을 두고 있는 것으로 보인다. 2006년 평가 지표는 “성과 지표”라고도 일컬으며 다음과 같이 구성하고 있다.

지표는 크게 “업무영역”, “정관상사업”, “세부사업군”, “세부성과지 표” 총 4가지로 구분하고 있는데 현재 지표로 업무영역은 범주, 정관상사업과 세부사업군은 항목, 세부성과지표는 지표라고 볼 수 있다. 당시 내용을 구체적으로 살펴보면 위의 〈Table 1〉과 같다. 업무
영역을 보면, 지금 기준으로 스포츠보급은 생활체육, 국내 선수권 부여는 전문체육, 국제교류는 국제체육으로 볼 수 있다. 위의 첫 번째로 개발된 지표들은 현재 활용되고 있는 평가 지표의 골자라는

Table 2. 2008 Performance indicators

\begin{tabular}{|c|c|c|}
\hline Evaluation area & Evaluation contents & Details of the evaluation \\
\hline \multirow{4}{*}{$\begin{array}{l}\text { 1. Business } \\
\text { performance } \\
\text { area }\end{array}$} & Performance & \multirow{2}{*}{$\begin{array}{l}\text { ncrease or decrease of } \\
\text { players, strengthen their } \\
\text { coaching capabilities, } \\
\text { player protection index, } \\
\text { and promotion of sports }\end{array}$} \\
\hline & Supplies of events & \\
\hline & Managing the game & The competition activities \\
\hline & $\begin{array}{l}\text { International } \\
\text { exchange }\end{array}$ & $\begin{array}{l}\text { The activity of international } \\
\text { competition }\end{array}$ \\
\hline \multirow{4}{*}{$\begin{array}{l}\text { 2. Organizational } \\
\text { performance } \\
\text { area }\end{array}$} & Fiscal accounting & $\begin{array}{l}\text { Financial independence and } \\
\text { accounting soundness }\end{array}$ \\
\hline & Human resources & Activating the committee \\
\hline & $\begin{array}{l}\text { Promote it to the } \\
\text { public }\end{array}$ & $\begin{array}{l}\text { Promoting to the outside } \\
\text { world }\end{array}$ \\
\hline & $\begin{array}{l}\text { Office work } \\
\text { cooperation }\end{array}$ & Cooperation in office work \\
\hline
\end{tabular}

(KISS, 2008)

Table 3. Evaluation and comparative analysis of the preparation stage

\begin{tabular}{|c|c|c|}
\hline Sortation & 2006 & 2008 \\
\hline Evaluation name & $\begin{array}{l}\text { Development and evaluation of performance indicators for economic } \\
\text { organizations. }\end{array}$ & Performance evaluation of sports organizations \\
\hline Evaluation Goal & Organizational operation and business evaluation & $\begin{array}{l}\text { Strengthen equity, transparency, } \\
\text { and efficiency in performance support costs }\end{array}$ \\
\hline Evaluation target year & - & 2007 \\
\hline $\begin{array}{l}\text { The number of } \\
\text { subjects to be } \\
\text { evaluated }\end{array}$ & $\begin{array}{l}43 \\
\text { C1: Performance-oriented event (14) } \\
\text { C2: The supply-oriented event (16) } \\
\text { C3: A compromise (23) }\end{array}$ & $\begin{array}{l}50 \\
\text { Ga Group (33): Olympic sports } \\
\text { Na Group (17): Sports other than Ga group }\end{array}$ \\
\hline Category & $\begin{array}{l}\text { Distribution of sports, game management, fostering excellent athletes, } \\
\text { international exchange }\end{array}$ & Business performance, organizational performance \\
\hline The result level & $\mathrm{A} \sim \mathrm{E}$ & 100 points \\
\hline
\end{tabular}

(KISS, 2008)

1) 탁구, 핸드볼, 역도, 복싱, 빙상, 유도, 체조, 레슬링, 하키, 사격, 펜싱, 태권도, 배드민턴, 양궁 이상 14개

2) 육상, 축구, 테니스, 정구, 사이클, 배구, 럭비, 수영, 스키, 승마, 요트, 골프, 보디빌딩, 세팍타크로, 우슈, 당구 이상 16 개

3) 택견, 씨름, 궁도, 농구, 야구, 아이스하키, 검도, 조정, 인라인롤러, 볼링, 카누, 근대5종, 수상스키, 산악, 수중, 소프트볼, 루지, 컬링, 트라이애슬론, 바이애슬론, 스쿼시, 공수도, 댄 스스포츠 이상 23 개

4) 육상, 핸드볼, 역도, 복싱, 유도, 체조, 레슬링, 하키, 사격, 태권도, 양궁, 배드민턴, 펜싱, 축구, 테니스, 탁구, 농구, 배구, 사이클, 수영, 야구, 스키, 승마, 조정, 카누, 요트, 근대5종, 바이애슬론, 소프트볼, 트라이애슬론, 아이스하키, 컬링 이상 32 개

5) 정구, 럭비, 볼링, 골프, 보디빌딩, 세팍타크로, 스쿼시, 우슈, 당구, 인라인롤러, 씨름, 검도, 궁도, 수상스키, 산악, 수중, 루지 이상 17 개 
것을 확인할 수 있는데 우리나라 종목단체들을 평가하는 시작점에 있어 상당한 의미를 부여할 수 있다. 평가지표명을 살펴보면 첫 시기인만큼 지표명이 난해하거나 업무영역부터 세부성과지표까지 연계성이 부족하다. 가령 “스포츠보급 영역”의 “기타 본회의 목적 달성”에 필요한 사업, “국내 선수권 부여 영역”의 “경기 시설에 관한 연구와 설치 및 관리”의 연계성이 매우 떨어진다.

2008년 평가지표는 “평가 영역”과 “평가 내용”으로 구분하였다. 앞서 2006년과는 달리 평가 지표에 대한 변화가 눈에 띤다. 평가 영역은 다시 사업성과와 조직성과로 구분하였는데 이때 사업성과는 경기력, 종목 보급, 경기 관리, 국제교류로 그리고 조직영역에는 재정회계, 인력 자원, 대외 홍보, 사무 협력 총 4 개의 지표를 각각 만들었다. 이를 아래의 〈Table 2〉에 정리 제시하였다.

\section{5. 평가 환류}

평가에 따른 환류를 어떻게 적용하는 지에 대한 부분으로 두 가지 안이 제시되었다. 첫째, 평가 결과 공개, 둘째, 경기단체별 평가결과를 차기년도 기금 및 국고사업의 재원 배분에 반영시키는 안이다. 평가결과 공개는 내부 공개와 국민대상으로 완전 공개로, 재원배분은 성과결과를 반영하여 재원을 차등지급하는 안이다. 다만 2007년과 2008년 자료를 살펴보면 평가 환류에 대한 언급은 전무한 것으로 보인다.

\section{6. 시사점}

준비기는 평가제도를 도입하기 위한 초기로 어려움이 다수 발견된다. 2009년 초 대한체육회 회장 선거를 앞둔 시기로 경기단체장이 대한체육회장 선거권을 갖고 있기 때문에 평가를 회피하는 피평가자의 성향이 선거 시기와 겹쳤다는 점, 가맹경기단체 회장선거를 일시에 치르게 되어 일손이 부족한 경기단체로부터 자료 확보가 어려웠던 점, 지표 설계가 불명확한 점, 전문성을 갖춘 평가위원 미확보, 평가를 제도적으로 보장하지 않은 상태에서 본 평가 작업은 경기단체가 발표하거나 제공한 제한적인 자료에 의존함으로써 많은 지표 평가를 하기 어려움(KISS, 2008) 등 초기 단계에 발생할 수 있는 애로사항들이 있었다.

그러나 무엇보다 이전까지 전무했던 평가에 대해 경기단체들의 반발심이 가장 큰 문제점은 아니었을까라는 추측이 든다. 당시 경기단체 사무국장과 대한체육회 직원을 대상으로 실시한 심층면접에 의하면, 평가에 대한 경기단체의 입장, 반발 원인 및 해결 방안 등이 대부분의 내용이었다(KISS, 2006).

이렇게 준비기는 평가 체계 및 운영 그리고 평가 인식 확산을 위해 평가에 대한 필요성 및 당위성 확보, 객관적인 평가 지표 개발, 체계적인 평가 운영 구축 등에 심혈을 기울인 시기라 할 수 있다.

\section{실행기(2010-2015)}

실행기는 지금의 평가가 지속될 수 있었던 때이며 실제 평가 운영 및 지표가 체계성을 갖추었던 중요한 시기였다. 평가에 대한 인식 및 근거 부족, 경기단체 특성을 고려한 군분류 및 지표의 타당성 문제 등 어려움을 겪었던 시기였다.

하지만 이러한 한계 및 문제점을 개선하기 위해 체육과학연구원(현 한국스포츠정책과학원)은 경기단체 성과평가 운영 방향 및 근거 강화에 대한 연구를 실시하는 등 연구기관을 통한 지속적인 개선 작업을 이어갔다. 이 시기는 2010년 한해 동안은 시범평가를
실시하였고, 이후 매년 관례대로 평가가 운영되는 동시에 지속적으로 지표 수정 및 운영에 대한 개선이 이루어지는 시기라 할 수 있다. 이에 대한 세부적인 내용은 아래와 같다.

\section{1. 근거}

「2010 경기단체 조직운영 평가」보고서에 의하면 평가 근거를 찾을 수 없었는데 대신 대한체육회의 내부지침에 의거하여 평가가 수행되었을 것이라 추측된다. 왜냐하면 3년이 지난 2013년 11월 대한체육회 평가위원회 규정이 마련되었다는 기록이 있기 때문이다. 이후 통합대한체육회 발족과 동시에 2016년 3월 평가위원회 운영 규정을 재차 만들어 이후 2020년까지 적용하였다. 평가위원회 규정을 살펴보면, 총 21 조로 구성되어 있는데 위원회의 기능 및 구성, 평가단 세부 운영 사항 등을 제시하고 있다.

\section{2. 목적}

2006년과 2008년 두 번에 걸친 평가는 성과 중심의 단순 평가라 해석하고, 이를 개선하기 위해 경기단체의 조직운영의 합리성, 윤리성 및 사회적 책임성 등을 강화하고자 하였다(KISS, Deloitte, 2010). 즉 이전 경기단체의 국제대회 성적이나 우수선수 육성 실적에 초점을 두었다면 실행기에서는 경기단체의 조직운영 방식을 개선하기 위해 선수, 감독 선발 시 불공정행위, 불투명한 회계 관리, 성차별 관행, 비민주적인 행태 등으로 불공정행위를 근절시킬 수 있는 평가지표를 개발하고 운영을 체계화하였다. 2016년 통합체육회 발족까지 평가는 경기단체의 사회적 책임 의식 강화, 조직운영 능력 향상 및 투명성 강화, 평가를 통한 경기단체의 체질 개선 등을 목적으로 하고 있다.

\section{3. 평가 체계}

2011년부터 안정적인 평가시스템으로 정착시키고자 2010년 시범평가 결과에서 발견되었던 문제점을 분석하고, 경기단체 의견을 수렴하여 평가지표와 평가방식을 개선하기 시작했다. 이 시기 평가보고서 및 증빙자료에 대한 검증 작업을 강화하고, 경기단체의 불이익을 방지하고자 평가결과에 대한 피평가기관의 이의신청 및 조정 절차 등을 도입하였다. 그리고 폭력, 비리 등 문제가 발생된 단체의 경우 평가 점수는 산출하지만 평가순위에서 제외와 인센티브 포상단체에 포함되지 않도록 별도로 관리하였다.

2013년부터 2016년까지 경기단체 조직운영 평가에서는 경기단체의 특성을 반영하여 동일 집단으로 묶어 평가하고자 평가군(가/나/다/라) 분류를 실시하게 되었다. 물론 준비기에서도 평가군을 구분한 기록을 찾을 수 있으나 평가 대상수의 급증, 평가 기준을 설정하여 현재까지 이 기준을 따르고 있는 것으로 나타났다. 이때 평가군 구분 기준은 올림픽·아시안게임종목, 3 년간 예산 규모 등을 고려하였고, 평가군별로 평가범주의 배점을 차등화하여 평가를 실시하였다.

이 시기 평가체계에서 두드러진 점은 평가 결과에 대한 환류체계 강화, 대한체육회 평가위원회 규정에 의거 체계적인 평가 운영이라 할 수 있다. 환류체계 강화라 함은 평가 결과를 인센티브와 경기력향상지원비 배분 기준으로 활용하였고, 부진단체에 대해서 삼진아웃제를 시행하는 등의 조치로 볼 수 있다. 아울러 평가위원회 규정에 의거하여 전문평가단 구성, 종목단체에서 발생된 범죄 사실 확인에 따른 제재방안 등을 명문화하였다. 이러한 방안들은 실행기 
평가에 대한 인식을 강화시키는 것은 물론 각 지표별 종목단체들의 수준을 비교 분석하여 결과에 대한 컨설팅 작업을 하는 데에 중요한 역할을 하였다.

\section{4. 평가 지표}

2010년 평가 지표는 평가영역(3개)과 평가지표(16개)로 구성되었다. 평가영역은 (가리더십, (나핵심사업의 윤리성, (다재무관리이다. (가리더십(6개지표)은 비전 및 전략제시/이사회·위원회 구성의 투명성/합리적·민주적 단체운영/재정기여도/국제교류사업의 합리성/체육선진화 정책과제 기여도, (4)핵심사업의 윤리성(6개지표)은 대표팀 지도자 관리/대표선수 관리/경기성적 공정관리/선수폭력방지 및 보호노력/심판제도운영/윤리교육, 다재무관리(3개지표)는 회계 및 결산과리 합리성/예산운영관리의 적정성/재무성과로 각각 구성되어 있다(KISS, Deloitte, 2010).

2011년 평가 지표는 평가영역을 가전략/의사결정 합리성, (나핵심사업 관리의 윤리성, 다재무관리로 구성하였고(KISS, Deloitte, 2011). 이전 해 리더십에 포함되었던 재정기여도를 재무관리의 재무성과로 통합하였으며, 이외 평가 지표는 2020년과 동일하다.
2012년 평가는 2011년 평가영역 및 평가지표 모두 동일하였다. 이는 2010년 시범사업 이후 평가에 대한 인식도를 확산시키고 무엇보다 회원종목단체 평가 담당자가 지표에 대한 충분한 이해를 갖기 위한 시간이 필요한 것으로 보인다.

2013년에는 기존 평가지표 수를 축소한 것이 특징이다. 평가영역(3개)은 동일하되 카전략/의사결정 합리성( 6 개 $\rightarrow 3$ 개)은 비전·발전계획 합리성/책임경영 합리성/체육회 정책실행 합리성, (44)핵심사업 관리의 윤리성(7개 $\rightarrow 6$ 개)은 종목보급 합리성/우수선수 육성 합리성/선발관리 합리성/경기관리 합리성/국제교류 사업 합리성/핵심사업 윤리성, 다재무관리(동일) 영역별 지표를 새로 만들고, 지표 수를 감소시켰다.

2014년 평가는 2013년 평가영역 및 평가지표와 모두 동일하다. 2015년 평가 지표에서 주목 할 점은 핵심사업 범주에 재무 성과와 윤리성 강화와 관련하여 지표 이동 및 새롭게 개발되었다. 체육계 비윤리적 행태가 사회적 물의를 빚어낸 영향으로 이해할 수 있다.

실행기에서 평가 지표의 특징은 2년 주기설이다. 즉 2013년과 2014년 그리고 2012년과 2013년 평가 영역 및 평가 지표가 모두 동일한 것을 발견할 수 있었다.

Table 4. Evaluation and comparative analysis of the implementation stage

\begin{tabular}{|c|c|c|c|c|c|c|}
\hline Sortation & 2010 & 2011 & 2012 & 2013 & 2014 & 2015 \\
\hline Evaluation name & $\begin{array}{c}\text { Organizational } \\
\text { Management } \\
\text { Evaluation of a } \\
\text { Sports Organization }\end{array}$ & \multicolumn{3}{|c|}{$\begin{array}{c}\text { Organizational Management } \\
\text { Evaluation of a Sports Organization }\end{array}$} & $\begin{array}{c}\text { Advanced } \\
\text { Evaluation of Sports } \\
\text { Organizations }\end{array}$ & $\begin{array}{c}\text { Organizational } \\
\text { Management } \\
\text { Evaluation of a } \\
\text { Sports Organization }\end{array}$ \\
\hline $\begin{array}{c}\text { Evaluation target } \\
\text { year }\end{array}$ & 2009 & 2010 & 2011 & 2012 & 2013 & 2014 \\
\hline $\begin{array}{l}\text { The number of } \\
\text { groups }\end{array}$ & 55 & 55 & 55 & 56 & 56 & 70 \\
\hline Evaluation period & '10.4. 7. & '11.3. 6. & '12.4. 6. & '13.6. 11. & '14.5. 12. & ‘15.4. 12. \\
\hline $\begin{array}{l}\text { Evaluation } \\
\quad \text { Goal }\end{array}$ & $\begin{array}{l}\text {-Stabilize the } \\
\text { objective evaluation } \\
\text { system. } \\
\text { - Reinforcing the } \\
\text { rationality and } \\
\text { transparency } \\
\text { of sports } \\
\text { organizations. } \\
\text { - Lead the } \\
\text { development with } \\
\text { ethical organization }\end{array}$ & $\begin{array}{l}\text { - Executive } \\
\text { evaluation of the } \\
\text { administration } \\
\text { of sports } \\
\text { organizations. } \\
\text { - Improving the } \\
\text { constitution of } \\
\text { sports organizations } \\
\text { through evaluation }\end{array}$ & $\begin{array}{l}\text { - Strengthen the } \\
\text { sense of social } \\
\text { responsibility } \\
\text { of sports } \\
\text { organizations. } \\
\text { - Improving the } \\
\text { constitution of } \\
\text { sports organizations } \\
\text { through evaluation }\end{array}$ & $\begin{array}{l}\text { - Classification of } \\
\text { evaluation groups } \\
\text { reflecting the } \\
\text { characteristics } \\
\text { of each sports } \\
\text { organization. } \\
\text { - Improving } \\
\text { organizational } \\
\text { management } \\
\text { skills of sports } \\
\text { organizations }\end{array}$ & $\begin{array}{l}\text { - Improving } \\
\text { organizational } \\
\text { management } \\
\text { capabilities and } \\
\text { solving chronic } \\
\text { management } \\
\text { problems. } \\
\text { - Achieved the goal } \\
\text { of establishing a } \\
\text { sports organization }\end{array}$ & $\begin{array}{l}\text { - Establishing rational } \\
\text { transparency } \\
\text { in organization } \\
\text { management. } \\
\text { - Develop into an } \\
\text { ethical organization }\end{array}$ \\
\hline $\begin{array}{l}\text { Category/item/ } \\
\text { indicators } \\
\text { (Number) }\end{array}$ & $3 / 16 / 37$ & $3 / 16 / 38$ & $3 / 16 / 38$ & $3 / 12 / 23$ & $3 / 12 / 28$ & $3 / 12 / 29$ \\
\hline Name of category & $\begin{array}{l}\text { - Leadership } \\
\text { - The ethics of the } \\
\text { core business. } \\
\text { financial } \\
\text { management }\end{array}$ & $\begin{array}{l}\text {-Rationality of strates } \\
\text {-The ethics of the cor } \\
\text {-Financial manageme }\end{array}$ & $\begin{array}{l}\text { gy/decision making. } \\
\text { e business. } \\
\text { ent }\end{array}$ & $\begin{array}{l}\text { - Strategy/leadership } \\
\text { - Rationality and eth } \\
\text { - Appropriateness of }\end{array}$ & $\begin{array}{l}\text { rationality } \\
\text { cs of core businesses. } \\
\text { financial management }\end{array}$ & $\begin{array}{l}\text { - Strategy/leadership } \\
\text { - Key business. } \\
\text { financial } \\
\text { management }\end{array}$ \\
\hline Result grade & & & & $\sim \mathrm{D}$ & & \\
\hline
\end{tabular}

(KISS, 2010, 2011, 2012, 2013, 2014, 2015) 


\section{5. 평가 활용}

2011년부터 평가결과에 따라 인센티브와 경기력향상 지원비를 배분하기 시작했다. 그리고 각 경기단체들이 규정을 인식하고 따르기 위해 평가매뉴얼을 만들어 배포하는 등 현장에서 평가 운영이 원활할 수 있도록 지속적인 개선의 노력이 이어졌다. 〈Table 4〉 는 2010년부터 2015년까지 체육단체 평가에 대한 내용들을 비교 분석하였다.

\section{구축기(2017 2020)}

구축기는 준비기와 실행기를 거쳐 종목단체에게 평가에 대한 인식이 확산되고, 평가 운영이 안정화 된 시기라고 할 수 있다. 특히 대한체육회가 통합 된 후 실시하였기에 단체들의 발전 방향성 그리고 효율적인 평가 운영에 대한 개선이 필요한 시기였다. 이 때 2016년 대한체육회와 국민생활체육회의 단체 간 통합되는 시기로 평가를 실시하지 않았다. 다만, 통합체육회 창설에 따라 기존 평가 운영 체계는 대부분 그대로 수용되는 반면 평가가 지향해야 할 방향과 목적, 평가 지표 변화가 있었던 시기이다. 이에 대한 구체적인 내용은 다음과 같다.

\section{1. 근거}

그 동안 평가는 2014년 4월 1일 제정된 대한체육회 평가위원회 규정에 의거하여 수행되었다. 그러던 중 2016년 통합대한체육회는 평가위원회 규정을 새로 마련하면서 2020년까지 이 규정에 의거하여 평가를 수행했다. "평가위원회 목적은 제2조 평가업무의 공정성을 확보하고 효율성을 높이기 위하여 설치한 평가위원회의 구성과 운영 등에 관하여 필요한 사항을 정하는 것을 목적으로 한다". 이 외 평가위원회의 기능 및 구성, 평가단 세부 운영 사항, 심의 의결 내용 등을 담고 있다.

\section{2. 목적}

2016년 3월 21일, (구)대한체육회와 (구)국민생활체육회 통합과 산하 회원종목단체 간 통합으로 평가는 실시하지 않았다. 이후 2017년부터 재기된 평가를 “선진화 평가”라는 명칭으로 회원종목단체의 경쟁력 제고하기 위한 이상적인 조직 운영 가이드라인을 제시하고, 지속적인 피드백을 시행함으로써 조직운영 성과 개선을 이끌어나가고, 체계적인 평가를 통해 조직의 문제점과 개선 방안 도출 및 효율적인 단체 관리와 지원을 하는 데에 있다고 목적을 밝히고 있다(대한체육회, 2017). 이러한 동일한 목적으로 평가는 2020년까지 지속되어 왔다.

\section{3. 평가 체계}

이전 평가군 설정 방식은 지속적으로 문제 제기가 있어온 바 새롭게 통합된 회원종목단체의 다양한 특성을 최대한 고려하여 그룹화하고자 기준을 선정하였다. 그 기준이란 올림픽 및 아시안게임 종목 여부, 예산규모, 생활체육과 전문체육 특성, 정회원과 준회원단체 등이다. 이전까지만해도 올림픽·아시안게임 종목과 예산 규모 두 가지 기준만을 적용하여 종목단체들을 군별 구분하였으나 새로운 세부 기준을 설정한 것으로 보인다. 그리고 군별 종목단체 구분 외에 구축기에는 좀더 체계화된 구조를 확인할 수 있다. 이전에는 평가 수행에 주로 초점이 맞춰졌다면 이 시기에는 평가 이전인 준비단계를 강화시킨 것으로 보인다. 평가편람 배포 및 설명회 개최, 보고서 작성 상담 등 종목단체 담당자들의 보고서 작성 시 애로사항에 대한 문제점을 해결하려는 노력 등이다. 그리고 준비단계에서 종목단체들의 관리단체 지정으로 인한 평가 유예, 평가군에 대한 수용 여부에 대해 의견을 제출할 수 있는 기회가 마련되기도 하였다.

Table 5. Evaluation and comparative analysis of the construction stage

\begin{tabular}{|c|c|c|c|c|}
\hline Sortation & 2017 & 2018 & 2019 & 2020 \\
\hline Evaluation name & \multicolumn{4}{|c|}{ Evaluation of Advancement of Korean Sport \& Olympic Committee Member Sports Organization } \\
\hline Evaluation target year & 2016 & 2017 & 2018 & 2019 \\
\hline Number of groups & 62 & 61 & 61 & 65 \\
\hline Period & '17.4. 12. & '18.5. 12. & ‘19.7 12. & '20.7.6 12. \\
\hline Goal & \multicolumn{4}{|c|}{$\begin{array}{l}\text { - Improving the competitiveness of member sports organizations and presenting guidelines for organization operation } \\
\text { - Improving organizational operational performance through continuous feedback } \\
\text { - Derive organizational problems and improvement measures and support efficient group management }\end{array}$} \\
\hline Category/item/indicators & $5 / 13 / 24$ & $5 / 13 / 25$ & $6 / 15 / 39$ & $6 / 16 / 40$ \\
\hline Name of category & \multicolumn{4}{|c|}{$\begin{array}{ll}\text { - Performing major projects and establishing a virtuous cycle - Performing major projects and establishing a virtuous cycle } \\
\text { - Governance established } & \text { - Governance established } \\
\text { - Control and reflux system established } & \text { - Control and reflux system established } \\
\text { - Additional points } & \text { - Autonomous indicators by group } \\
& \text { - Policy indicators }\end{array}$} \\
\hline Result grade & \multicolumn{4}{|c|}{$\mathrm{S} \sim \mathrm{D}$} \\
\hline
\end{tabular}

(KISS, 2017, 2018, 2019, 2020) 


\section{4. 평가 지표}

통합 이후 생활체육, 전문체육, 학교체육의 선순환 시스템 구축 그리고 체육계 윤리문제, 투명한 조직관리, 스포츠비리 근절 및 'good governance' 에 대한 내용을 평가지표로 반영한 것이 이 시기 환경적인 배경이라 할 수 있다. 실행기였던 2015년과 구축기인 2017년 평가 지표의 변화가 크다. 즉 이전까지 평가영역과 평가지표(영역 $\rightarrow$ 지표)로 두 단계였던 것이 2017년부터 평가범위, 평가항목, 평가지표로 세단계(범주 $\rightarrow$ 항목 $\rightarrow$ 지표)로 구분되었다. 그만큼 지표수 증대가 단계에도 큰 영향을 준 것으로 이해된다.

2017년 평가범주는 4개로 (가리더십, (4)주요사업 수행 및 선순환 구조 정착, 다거버넌스 확립, 라통제 및 환류체계 정착이다. (가리더십(3개항목/5개지표) 중 항목은 비전전략/조직 역할과 의무, 자립기반 3개로 이에 속한 세부지표는 총 5개다. (4)주요사업 수행 및 선순환 구조 정착(6개항목/10개지표) 관련 항목은 학교체육, 우수선수, 생활체육, 리그/대회, 지도자/심판, 은퇴선수 총 6 개 항목으로 이에 속한 세부지표는 총 10 개이다. (다거버넌스 확립(2개항목, 4개지표) 중 항목은 윤리성 및 투명성, 민주성 및 혁신성 총 2 개 항목으로 비리근절, 혁신적 제도개선 등 세부지표로 총 4개이다. 라통제 및 환류체계 정착(1개항목, 2 개지표)은 항목 명칭 또한 범주와 동일하며, 내부통제 및 환류시스템 구축 등 세부지표로 총 2 개이다. 이외 가감점으로 통합노력(가점)과 비리건수(감점)를 추가로 만들었다.

위와 같이 구성된 2017년도 평가지표는 2018년까지 동일하게 운영되었으며, 2019년에는 총 4개의 범주 외 “단체별 자율지표"를 새롭게 추가하여 범주는 총 5개로 증가하였다. 단체별 자율지표는 종목을 반영하여 특화된 사업을 추진했을 경우 제시하는 지표이다. 2019년 평가지표는 2020년까지 큰 수정 없이 지속 운영되어 왔다.

\section{5. 평가 활용}

평가결과에 따라 인센티브와 경기력향상지원비를 차등 지급하였다. 위의 내용을 토대로 2017년부터 2020년까지 평가에 대한 내용을 비교 분석한 것은 〈Table 5〉와 같다.

\section{결론 및 제언}

2006년 처음으로 종목단체에 대한 평가 운영 계획안이 만들어지기 시작한 이후 2021년 현재 “체육단체 혁신 평가”가 수행 중이다. 15 여년 동안 이어져 온 평가는 준비기, 실행기, 구축기를 거치며 목적, 대상, 지표 및 환류 등 다양한 내용으로 아래와 같이 변모하였다.

첫째, 평가 체계 및 지표 개발을 위한 준비기(2006 2009)이다. 2006년 경기단체 조직운영 평가, 2008년 평가지표 개발 및 시뮬레이션을 위한 연구가 두 차례에 걸쳐 진행되었다(KISS, 2008). 체육과학연구원이 수행한 「2006 대한체육회 가맹경기단체 성과평가」(2006.12)와「2008 경기단체의 성과평가」(2008.12)가 바로 그것이다.

준비기에는 평가를 위한 사회적 배경 및 필요성, 유사 사례에 대한 분석을 제시하고 있다. 우선「경기단체 성과지표 개발 및 평가」(2006)에서 평가목표는 경기단체 조직 및 사업 전반적인 운영에 대한 평가를 위한 것이며, 평가지표는 평가영역의 포괄성과 차별성에 기준을 두고 있다. 다양한 경기단체들을 평가하는 데에 있어서
포괄성은 “보편성”을 그리고 차별성은 “특수성”을 기준으로 한다는 의미이다. 두 가지 기준을 근거로 경기단체 사업(종목보급, 경기관리, 우수선수육성, 국제교류), 경기단체 조직성과(고객만족도 제고, 재무·예산관리의 합리화, 체계적인 인적자산 관리 강화, 지속적 혁신 및 내부역량 강화)에 대한 평가 지표를 개발하였다.

2008년 평가 특징은 평가에 대한 의무가 강조되고 있음을 확인할 수 있다. "공공재원의 지원이 있으면 성과가 평가되는 성과관리 예산제도로 변화하는데 국고보조금 사업이나 체육진흥기금지원사업에 대한 성과 평가에 응하는 것이 선택이 아닌 의무이다(KISS, 2008)“라고 하였다. 당시 대한체육회는 경기력 지원비 규정을 마련하여 경기단체를 5등급으로 분류 및 경기력지원비를 차등 지원해왔다. 이 때 지원금은 성과와 연동되어 있지 않아 형평성과 투명성에 대한 문제점이 지속적으로 대두되었기에 종목단체 평가에 대한 역할론과 중요성은 동시에 강조되었다.

이렇게 준비기는 평가를 위한 준비 단계로 전문 평가단 및 평가 자료 미확보, 담당자의 평가에 대한 인식 부족, 평가에 대한 거부감, 무엇보다도 평가를 제도적으로 보장하지 않은 상황에서 체계적인 평가를 수행하기가 매우 어려웠던 시기였다. 그럼에도 불구하고 평가군 설정(가군: 올림픽종목, 나군: 가군 이 외 종목으로 아시안게임, 비해당종목), 평가 항목[사업성과(경기력, 종목보급, 경기관리, 국제교류), 조직영역(재정회계, 인력자원, 대외홍보, 사무협조성)]을 만들었다. 평가 항목의 경우 2010년부터 본격적으로 운영되었던 평가 지표로 그대로 반영된 것을 확인할 수 있다.

둘째, 종목단체에 대한 평가가 본격적으로 수행되었던 실행기(2010 2015)이다. 경기단체의 회계부정, 회장선거 비리, 승부조작, 비리 전력자 임원 장기 독점 등 고질적 문제점 해결, 체질 개선과 체육계 자정 기회로 삼고자 했던 시기였다. 그 당시에도 조직의 합리적 운영, 그리고 윤리성을 주요 척도로 설정하였는데 지금과 같이 윤리성에 어긋나는 체육단체들의 문제점이 만연하였고, 이에 대한 개선을 위한 적극적 개입 즉, 평가 지표로 반영한 것이다. 2010년은 시범적으로 평가를 수행했던 때였던 만큼 52개 단체가 첫 평가 대상이다. 이때 평가위원 구성, 설명회 개최, 증빙자료 제출 등 평가를 위한 준비 단계를 마련하였고, 평가범주(3개)는 리더십, 핵심사업의 윤리성, 재무관리, 지표는 16개로 구성되었다. 2010년 “경기단체 조직운영 평가”는 2014년까지 이어져오다 2014년 “경기단체 선진화 평가”, 2015년 “경기단체 조직운영 평가”로 명칭이 변경되었다. 2013년도의 경우 그 동안 모든 단체들이 동일하게 평가받았으나 올림픽 및 아시안게임종목, 기타 생활체육종목, 예산 대·소규모 등의 기준에 따라 구별되어 평가를 받기 시작했다. 동년 11월에는 대한체육회 평가위원회 설치에 대한 규정을 마련하였고, 체육단체들은 전면적으로 외부회계 감사를 실시하게 되었다.

실행기는 평가운영에 있어 가장 큰 변화의 시기라 할 수 있다. 평가 대상이 2010년 55개에서 2015년 70개로 증가했던 반면 지표수는 2010년 37개에서 2015년 29개로 감소 추세를 보였으며 평가 결과에 따라 등급(S D)에 따라 2011년부터 인센티브를 지원하기 시작하였다. 아울러 6여년동안 평가위원회 규정, 평가군, 평가지표, 인센티브 등 평가 체계에 대한 지속적인 개선이 이루어졌다.

셋째, 통합대한체육회 이후 종목단체 평가가 재기된 시기로 평가 운영 및 지표 체계가 개편되었던 구축기(2017 2020)이다. 2016년 대한체육회와 국민생활체육회 통합으로 평가는 실시하지 않았던 대신 대한체육회는 「회원종목단체 조직운영 평가 제도개선 연구」를 
발표하였다. 기존 평가에 대한 현황 및 문제점을 진단하였고, 이를 기반하여 2017년부터 2019년까지 평가가 실시되었다. 그리고 2016년 3월 대한체육회 평가위원회 규정이 재정립되면서 “선진화평가”라는 명칭이 체육단체들에게 보편화된 용어로 사용되었다. 2017년 평가에서 큰 변화는 범주의 확대라 할 수 있다. 즉, 2015년 전략/리더십, 핵심사업, 재무관리 총 3개의 범주였던 것이 리더십, 주요사업수행 및 선순환구조정착, 거버넌스 확립, 통제 및 환류체계 정착, 가감점 등 총 5 개로 확대되었다. 범주 확대는 항목 및 지표수를 증가시켰고, 무엇보다 체육계의 비위행태들이 사회적 물의로까지 대두되면서 지표 수가 동시에 증대되었다. 스포츠비리 중에서도 큰 경우와 그에 비해 가벼운 경우, 정책지표 신설 등이 대표적인 예이다.

13 여년 동안 대한체육회 회원종목단체(정회원, 준회원, 인정단체)에 대한 평가는 준비기, 실행기, 구축기를 거쳐 정착되었다. 정무업무평가기본법 제 21 조에 의거 지방자치단체 또는 그 장이 위임받아 처리하는 국가위임사무, 국고보조사업, 그 밖에 대통령령이 정하는 국가의 주요시책 등 국정의 효율적인 수행을 위하여 평가가 필요한 경우에는 행정안전부장관이 관계중앙 행정기관의 장과 합동으로 평가를 실시할 수 있다. 대한민국 국고지원을 받는 조직들은 평가에서 예외가 없다는 의미이기도 하다.

평가란 그 가치를 판단하며 평가지표 하나하나에는 단체의 발전을 위한 지향점과 단체의 정체성 등 철학이 담겨 있다. 체육단체 평가는 수년간 수정 중이고 최근에는 평가 명칭과 지표에 대한 변화가 있었다. 평가는 절차와 결과 도출에 대한 공정성과 객관성은 물론 변화무쌍한 시대적 요구 또한 반영되어야 하기 때문에 지속적으로 수정·보완되는 것이다. 그러므로 후속 연구를 통해 2021년 체육단체 혁신 평가에 대한 문제점 및 개선 방안 그리고 앞으로 혁신 평가가 한국체육 100 년을 맞이하는 시점에서 필요한 조건들은 무엇인지 지속적인 통찰과 분석 개선이 요구된다. 


\section{참고문헌}

Kim, K. S. (2004). Governance and Performance of the Executive Agencies in Britain. Korean Journal of Public Administration, 13(3), 206-235.

Kim, S. J., \& Hong, S. P. (2009). Development of Ethics Management Model and its Promotion Strategy in Sport Organization. The Korean Journal of Physical Education, 48(4), 241-256.

Korea Institute of Sport Science(2006). Performance Evaluation of Member Sports Organization. Seoul: Korea Institute of Sport Science.

Korea Institute of Sport Science(2008). Performance Evaluation of Member Sports Organization. Seoul: Korea Institute of Sport Science.

Korea Institute of Sport Science · Deloitte(2010). Organizational Management Evaluation of a Sports Organization. Seoul: Korea Institute of Sport Science.

Korea Institute of Sport Science · Deloitte(2011). Organizational Management Evaluation of a Sports Organization. Seoul: Korea Institute of Sport Science.

Korean Sport \& Olympic Committee(2012). Organizational Management Evaluation of a Sports Organization. Seoul: Korean Sport \& Olympic Committee.

Korean Sport \& Olympic Committee(2014). Advanced Evaluation of Sports Organizations. Seoul: Korean Sport \& Olympic Committee.

Korean Sport \& Olympic Committee(2017). Evaluation of Advancement of Korean Sport \& Olympic Committee Member Sports Organization. Seoul: Korean Sport \& Olympic Committee.

Korean Sport \& Olympic Committee(2018). Evaluation of Advancement of Korean Sport \& Olympic Committee Member Sports Organization. Seoul: Korean Sport \& Olympic Committee.

Korean Sport \& Olympic Committee(2019). Evaluation of Advancement of Korean Sport \& Olympic Committee Member Sports Organization. Seoul: Korean Sport \& Olympic Committee.

Lee, C. K. (2009). Analysis of the evaluation system of public institutions in the UK and discussion of implications for Korea. Korean Journal of Policy Analysis and Evaluation, 19(2), 337373.

Lee, J. H., Han, J. H., \& Cho, M. H. (2006). The Development of Managemental Performance Evaluation Scale in Public Sport Organizations. The Korean Journal of Physical Education, 45(6), 419-427.

Lee, S. C., Lee, J. W., Shin, C. S., Jin, S. T., Na, S. H., Hong, S. P., \& Kwon, M. H. (2011). Comparative Analysis of Business Ethics Awareness Between Domestic and Foreign Sport Organizations. Korean Society For Sport Management, 16(5), 103-112.

Park, K. K. (2005). Precautions for the Process of Performance
Evaluation and the Use of Results. Seoul: Policy Think-Tank, Best in Korea.

Park, K. K. (2006). The Background and Purpose of the Introduction of the Performance Management System. Seoul: Policy ThinkTank, Best in Korea.

Regulations of the Evaluation Committee of the Korean Sport \& Olympic Committee. From https://www.sports.or.kr/ home/010708/0000/main.do\#

Regulations of the Member Sports Organization of the Korean Sport \& Olympic Committee. From https://www.sports.or.kr/ home/010708/0000/main.do\#

Seo, P. Y. (2005). British Administrative Reform Theory. Seoul: Daeyoung Co.

Shin, C. S. (2014). Development of Measurement Indicators to Enhance Ethical Management of Domestic Sports Organizations. Daejeon: National Research Federation of Korea.

Yoon, S. J., Lee, K. H., \& Hong, J. H. (2008). Comparative Analysis of Overseas Cases on the Performance Management System. Seoul: The Korea Institute of Public Administration. 


\section{대한체육회 회원종목단체의 평가 제도 변천사}

김미숙 ${ }^{1}$, 김자영 ${ }^{2}$, 김주영 ${ }^{2}$

1 한국스포츠정책과학원 스포츠정책연구실 책임연구위원

2 한국체육대학교

[목적] 이 연구는 2006년부터 2020년까지 대한체육회 회원종목단체 평가 운영 현황 및 체계 그리고 추이에 대한 비교 분 석을 하였다.

[방법] 이 목적을 달성하기 위해 문헌연구를 실시하였다.

[결과] 15년간의 평가는 준비기, 실행기, 구축기 3시기를 통해 발전되었다. 준비기(2006 2009)는 평가 지표 개발 및 운 영 체계를 갖추었던 시기였다. 실행기(2010 2016)는 지금의 체계를 갖추었던 중요한 시기였다. 평가 체계 및 운영, 지표 등 지속적인 변화 그리고 체육계에 평가 인식이 확산되었던 시기이다. 구축기(2017 2020)는 대한체육회와 국민생활체 육회 통합 이후 평가 체계가 안정적으로 구축되었던 시기였다.

[결론] 준비기, 실행기, 구축기를 통해 종목단체들의 조직 관리부터 윤리 경영까지 균형적인 성장을 촉진시키는 역할을 했다. 그리고 평가는 하나의 조직 평가는 물론 한국체육계의 지속적 성장과 변화를 반영하였다.

주요어

대한체육회 회원종목단체, 평가 제도, 정책 평가, 조직 운영 